\title{
Um aspecto da evolução fonética na família Tupí-Guaraní
}

\author{
Aryon Dall'Igna Rodrigues
}

O presente estudo constitui parte de um trabalho em elaboração, a respeito das diferenças fonéticas existentes entre os dois maiores ramos da família linguística Tupí-Guaraní: o ramo Tupí e o ramo Guaraní.

Como os estudos tupinológicos ainda não se firmaram definitivamente e como poucos têm sido os realizados neste setor da Glotologia, estudos esses que, em grande parte e, senão algumas exceções, na sua melhor parte, têm sido feitos fora do Brasil e são aqui mal conhecidos, faz-se mister que se explique aqui, antes de tudo, a nomenclatura usada neste estudo.

Família Tupí-Guaraní é a família linguística n. ${ }^{\circ} \mathrm{LXV}$ (tupy-guarany) da classificação de Paul Rivet, uma das maiores da América do Sul e aquela a que pertenciam as primeiras tribos encontradas pelos europeus no litoral brasileiro. Tal família compreende todos os dialetos (ou línguas: entre dialeto e língua, na Glotologia, não há distinção) provenientes duma língua préhistórica, o Proto-Tupi-Guaraní.

O Proto-Tupi-Guaraní ou Tupí-Guaraní comum é a língua que falava um tronco tribal que, vários séculos antes da chegada de Colombo ao continente americano, estava estabelecido na região que fica entre os rios Paraná e Paraguai; é "um estado linguístico homogêneo ou mais ou menos tal; é a primeira estratificação, a qual comporta particularidades linguísticas entrevistas antes da época histórica, i. é, antes dos fracionamentos dialetais”, na definição do ilustrado linguista patrício Prof. Mansur Guérios, que é o introdutor dos nomes Proto-Tupí-Guaraní, Proto-Tupí e Proto-Guaraní, ou Tupí-Guaraní comum, etc., na glotologia americana ${ }^{1}$.

Com o correr dos tempos, foi-se fracionando o primitivo tronco tribal e, do mesmo modo, a língua, o Proto-Tupí-Guaraní. Dos vários ramos em que

1. Rosário Farani Mansur Guérios, Novos Rumos da Tupinologia, Curitiba, 1935. págs. 3 e 4. 
se partiu o Proto-Tupí-Guaraní os principais foram o Proto-Tupí e o ProtoGuaraní.

O Proto-Guaraní ou Guaraní comum é a língua que ficou sendo falada nas regiões paraguaias e pelas tribos que se espalharam daí para o oriente, pelo sul do trópico de Capricórnio, até à costa atlântica. O Proto-Tupí ou Tupí comum é a língua que ficou sendo falada pelos índios que se afastaram mais da sua sede primitiva, estendendo-se pelo litoral, ao norte do trópico. Ambas as línguas apresentaram-se, em estado mais ou menos unitário, homogêneo, somente em época pré-colombiana. Fracionaram-se também, à sua vez.

Quando os europeus desembarcaram na costa brasileira, as tribos Tupí-Guaraní que eles encontraram comportavam dois conjuntos de dialetos: um, ao norte da linha tropical, proveniente do Proto-Tupí, outro, ao sul daquela linha, descendente do Proto-Guaraní. A esses dois conjuntos dialetais chamar-se-á aqui ramo Tupí e ramo Guaraní ou simplesmente Tupí e Guaraní, respectivamente. Não resta dúvida que houve e há outros ramos do antigo Proto-Tupí-Guaraní; só destes dois, porém, tratar-se-á aqui.

Considerando-se agora, por sua vez, os ramos Tupí e Guaraní, tem-se de reconhecer, ainda, mais uma divisão em cada um: o Tupí antigo e o Tupí moderno, por um lado, e o Guaraní antigo e o Guaraní moderno, por outro lado. O Tupí moderno - conjunto de dialetos Tupís hodiernos - tem o nome especial de Nheengatú e as tribos que o falam habitam a Amazônia; o Guaraní moderno - conjunto de dialetos Guaranís hodiernos - é chamado Avanheém, sendo falado no Sul do Brasil e Paraguai, principalmente.

Ao se assinalarem as diferenças fonéticas existentes entre os ramos Tupí e Guaraní, sempre tem sido frisada a contraposição dos vocábulos paroxítonos Tupí a vocábulos oxítonos Guaraní, desprovidos estes da última sílaba átona apresentada por aqueles. Os vocábulos dos dialetos do Proto-Tupí, nos séculos XVI e XVII, dialetos Tupí antigos, pois, e, certamente, o próprio Proto-Tupí, entretanto, não eram verdadeiramente paroxítonos: eram vocábulos oxítonos, cuja sílaba final constituía-se de (consoante) + vogal + consoante, e que se tornavam, na frase, paroxítonos, pela afixação de partículas (ou índices) vocálicas, monossilábicas e átonas, à consoante final, como, p. ex.: potár: potárŭ, poráng: poránga, piním: piníma, küsáb: küsábă, úbi: úbă, páb: pábi: pábã, úr. úri: úra, etc.

Examinando-se atentamente os vocabulários "brasílicos" de então, verifica-se que todos eles apresentam essas formas, quando não puramente terminadas em consoante $(-r,-m,-n,-k,-b,-n g)^{2}$, acrescidas das partículas vocálicas (-ă, -̌̆ ): - Padre Anchieta (1595): aiûr, acêm, apên, acepiác (= asepiák), apâb, aipotâr, aimeêng, ôca, ánga, etc.; Padre Luís Figueira (1620): ajúr, túba e túb, tinga, oca, tenycem, aixubán e ixubána, angaturáma e xeangaturám, etc.; Jean 
de Léry (1557): répiac (repiák), a-aub (= a’ób), yetic, se tam (= setám), auc (=ók), chè-encg (= xéáng), etc ${ }^{3}$.

Na obra do Padre Antônio Ruiz de Montoya $(1640)^{4}$, que apresenta o Guaraní antigo, esses vocábulos, quando isolados, apresentam-se sem a consoante final e, por conseguinte, oxítonos; quando em composição, diante de vogais, deixam aparecer a consoante final, tanto que o Padre Montoya, para distinguir esses vocábulos que terminam verdadeiramente em vogal tônica, convencionou escrever a consoante final separada da vogal tônica por um ponto, como, p. ex.: yû.r, tu.b, mẽ.n, oquẽ.n e cheróquẽnã, cã.m, mĩmbí.g, mandióg e mandió (apecûe), panẽ (: panẽmi), etc. Já no Guaraní de Montoya percebe-se claramente a ausência frequente do índice - $a$, portando-se, pois, esses vocábulos semelhantemente aos que terminam verdadeiramente em vogal, os quais nunca levavam tal índice.

Os mesmos vocábulos, ainda, nos dialetos Guaraní hodiernos, não mais apresentam vestígios da consoante final ${ }^{5}$, sendo definitivamente oxítonos (ou monossílabos tônicos) terminados por vogal: $y u, r u$, okẽ, mandi'ó, peté, etc ${ }^{6}$. Ao mesmo tempo, os dialetos Tupí hodiernos (Nheengatú) conservam ainda bem nítidas as formas paroxítonas, mais ainda do que os dialetos Tupí antigos : okéna, óca, ména, anãma, iauára, maniáca ("mandioca"), putíra, putári, cẽmo, amãna, etc ${ }^{8}$.

A única conclusão que se pode tirar desses fatos é, sem dúvida, que o Proto-Tupí-Guaraní possuía esses vocábulos terminados por consoante, i. é, "mén, “ók, *-úb, "sém, * páb, * potár, *áng, *kám, etc. Daí estabelecer-se-ão as seguintes leis fonéticas, na evolução do Proto-Tupí-Guaraní para o Proto-Guaraní e dialetos Guaraní modernos (Avanheém) e para o Proto-Tupí e dialetos Tupí modernos (Nheengatú): $-1^{\circ}$ ) as consoantes finais de sílabas tônicas

2. Seg. Anchieta (Arte de Gramática da Língua mais Usada na Costa do Brasil, ed. de 1933, p.8 v.) e Figueira (Arte de Gramática da Língua Brasílica, ed. de 1880, p. 101), às vezes, permutam-se o - $r$ por - $t$; segundo se vê em Anchieta, também - $b$ por $-p$ (V. nota 3). No tipo de vocábulos em questão também se enquadram os terminados pela semiconsoante $-y$. 3. É interessante observar que Léry raramente registra formas findadas em - $r$, apresentando sempre $-t$, do mesmo modo que apresenta $-p$ no lugar de $-b$.

4. Padre Antônio Ruiz de Montoya, Gramática y Diccionarios (Arte, Vocabulario y Tesoro) de la Lengua Tupí ó Guaraní, ed. de 1876, passim.

5 . Nos que findavam em $-m,-n,-n g$, restou a nasalação da vogal ora final, que precedia essas consoantes; há palavras, entretanto, que já perderam essa nasalação, em alguns dialetos. Alguns vocábulos monossilábicos, apenas, conservaram a consoante final: $t$-er- $a$, ang- $a$, men- $a$, kam- $a$, etc.; não mais se Ihes separa, porém, o antigo índice - $a$.

6. Antonio Ortiz Mayans, Breve Diccionario Guaraní-Castellano Castellano-Guaraní, Bs. Aires, 1941. 
(de vocábulos oxítonos) Proto-Tupí-Guaraní conservaram-se no Proto-Tupí; $2^{\circ}$ ) as consoantes finais de sílabas tônica (de vocábulos oxítonos) Proto-Tupí tornaram-se mediais nos dialetos Tupí modernos (Nheengatú), pelo desenvolvimento ou acréscimo de uma vogal breve $\left.(-\breve{a},-\tilde{e},-\breve{l}) ; 3^{\circ}\right)$ as consoantes finais de sílabas tônicas (de vocábulos oxítonos) Proto-Tupí-Guaraní desapareceram nos dialetos Guaraní modernos (Avanheém); esta última lei, no século XVII (quando foi registrado o Guaraní por Montoya), estava em pleno dinamismo, motivo por que se depara na obra do Padre Montoya o emprego mais ou menos arbitrário das formas com consoante final e sem consoante final. Esta fase evolutiva dos fonemas consoantes finais do Proto-Tupí-Guaraní no século XVII, pode, mais ou menos exatamente, ser comparada com a que se tem caracterizado no nosso português atual, aqui no Brasil (entre as populações das cidades), quando as mesmas pessoas pronunciam, ora fazer, ora fazế; ora andar, ora andá; ora fugir, ora fugí; ora vamos, ora vamo, etc. No português, entretanto, há um fator que procura reter o desenvolvimento do fenômeno, segundo a tendência inata dos indivíduos falantes: é o ensino da língua literária, que pretende uma fixidade máxima. Este fator, evidentemente, jamais poderia existir na língua indígena, e as exceções à lei fonética que se percebem nos atuais dialetos Guaraní são devidas a outra ou outras leis concorrentes.

7. No Nheengatú, o índice -ă perdeu o seu valor semântico e, simultaneamente, o afixal, passando a constituir parte inseparável dos vocábulos que o recebiam; por outro lado, a analogia e, ainda mais, a tendência manifesta pelas populações que falam o Nheengatú de facilitar a pronunciação, acrescentando após as consoantes finais uma vogal (-ă, - ẽ, $-\breve{\imath})$, também têm contribuído muito para a extensão do número de vocábulos paroxítonos nos dialetos Nheengatú. A respeito, note-se o que diz Couto de Magalhães, à pág. 2 do seu Curso de Língua Tupí Viva ou Nheengatu: "Quando o nome parece terminar em consoante, essa consoante é sempre seguida de um $a, e, i, o$ breves; a palavra casar alguns escrevem menar, eu, porém, escrevo menara, porque é assim que eles pronunciam, embora o último a seja quase imperceptível".

8. Gal. Couto de Magalhães, Curso de Língua Tupí Viva ou Nheengatu, in O Selvagem, do mesmo autor, $4^{\text {a }}$ ed., 1940, passim. 